\title{
sciendo
}

DOI 10.2478/sbe-2019-0021

SBE no. 14(2) 2019

\section{LEVERAGE AND MACROECONOMIC DETERMINANTS: EVIDENCE FROM UKRAINE}

\author{
DEARI FITIM \\ South East European University, Tetovo, Macedonia
}

MATSUK ZORIANA

Kyiv National Economic University after Vadym Hetman, Kyiv, Ukraine

LAKSHINA VALERIYA

National Research University Higher School of Economics, Moscow, Russia

\begin{abstract}
:
Viewed retrospectively since the work of Modigliani and Miller (M\&M, 1958), the capital structure still remains a matter of study. The capital structure issue then is examined from different perspectives, and thus intertwining firms and macroeconomic determinants. Studies were focused to examine the relationship between leverage ratios and macroeconomic environment. Motivated from what was done earlier, we try to bring in this study evidence as well. Thus, totally 49 Ukrainian firms are selected and data are examined from 2012 to 2016. The paper is aimed at studying the process of leverage adjusting by examining five firm's characteristics and three macroeconomic determinants. We found that leverage is influenced significantly from both, firm characteristics and macroeconomic determinants. The study provides evidence those firms with higher tax shield, tangibility, net trade credit, and profitability used more leverage than counterparties. Firm's size and inflation are confirmed as insignificant determinants. On the other hand, GDP growth rate and default spread are confirmed to play a role on leverage policies.
\end{abstract}

Key words: Leverage, Determinants, Macroeconomics

\section{Introduction}

The financial market provides an important basis for the accumulation of free savings and their further transformation into the investment capital. It satisfies the needs of the economic entities in financial resources. Efficiently organized securities market is one of the most important preconditions of the country's economic growth and of its citizens' social and economic well-being.

The integration of the domestic financial market into the global financial space and the processes of globalization have influence on the process of capital structuring. Thus, economic relations in the process of investment activities are improved and the structure of 
capital is transformed. The investigation of the firm's problems in the process of capital structuring and the search for the ways of their elimination causes the scientific interest and the need for their profound study.

The capital structuring is an important part of corporate policy of the firm which built its passive part of the balance with debts and equity. In defiance of the existing of a quite a few studies devoted to capital structure, there is no single theory, more over the conclusions of many papers are quite debatable. However, there is a few works which investigate the capital structure in emerging countries. But there is no sufficient work, which explains the process of the capital structuring in Ukraine. This paper explores some firm's characteristics and the selected macroeconomic factors influence on the capital structure for the sample of Ukrainian firms.

The article is organized as follows. After the introduction, we provide literature review about the capital structure and macroeconomic determinants. The third part deals with methodology and empirical results. And the last section summarizes the concluding remarks.

\section{Review of Literature}

Today, a significant number of scientists in their works try to identify factors that can influence on the process of the firm's structure formation. They explain what the capital structure should be, the principals of its formation and the determinants of its influence.

It is considered that the first theory is the Net Income theory, which was introduced by David Durand (1952). Its main idea is that the capital structure decision is connected to the value of the firm. This means that the modification of the financial leverage can corresponding influence on the change in the overall cost of capital as well as the total value of the firm.

According to the Durand's theory if the financial leverage grows larger, then the weighted average cost of capital becomes lower. The price of the firm and the market value of the equity shares enlargers. In return, if the financial leverage becomes less, then the weighted average cost of capital gets higher. The price of the firm and the market value of the equity shares decreases.

Nowadays the leading theory is the Miller-Modigliani theory, which consists of three parts.

The first part was published by the authors F. Modigliani and M. Miller in a collective publication in 1958. It is based on two theorems about the efficient market. According to the Theory 1 the market value of the corporation doesn't depend on its capital structure. It is determined by the level of the capitalization of the forecast income of the corporation. The Theory 2 is the logical continuation of the Theory 1 , and refers to the yield of shares of a corporation with a loan capital (Modigliani F. \& Miller M., 1958).

The second part examines the problem of capital structure in the presence of the corporate taxes. This causes the modification of two previous theorems under the influence of the tax shield. It allows to minimize the amount of tax burden at the expense of the increase of the loan capital quotas. Thus, the corporation's value with the loan capital is higher than the corporation value, which is financed by their own resources, on the 
dimension of the tax shield (1963). According to the Theorem 2 the capital structure influences the weighted average of corporation's capital value. The increase of the amount of the loan resources decreases the value of the capital, while its optimal level is actually achieved by the full loan financing (1963).

The third part, developed by Merton Miller (1977), reveals the previous issues in the presence of corporate and personal taxes.

The traditional theory is connected with names of J. Fred Weston and Ezra Solomon (1963). It characterizes the nature of the corporation and the investors' behavior. The main idea of the theory is that the optimal capital structure is achieved by the minimizing the weighted average cost of the corporation's capital and the maximizing its market value. The optimization of the capital structure gives an opportunity to increase its market value. This is possible due to an increase in the amount of borrowed capital to a certain limit, after which the cost of capital will begin to increase again (1963).

The compromise theory is associated with the names of scientists Alan Kraus and Thomas Litzenberger. It identifies the existence of a cost system. These costs are associated with bankruptcy or liquidation costs. The main idea of the compromise theory is as follows. The capital structure of the corporation should be based on the compromise between the tax advantages of the borrowed capital on the one hand and high interest rates and considerable expenses, which are connected to the bankruptcy on the other hand. The optimal is such capital structure in which the costs associated with the bankruptcy are offset by the benefits of the tax shield (Brigham, 2008)

The theory of the agency costs belongs to Michael $\mathrm{C}$. Jensen and William $\mathrm{H}$. Meckling (1973). It characterizes agency costs. These costs are associated with the management activities monitoring in order to control their implementation of all contractual obligations to creditors and shareholders (Van Horne J. C., 2008). The theory assumes that the interests between agents and principals do not always match. Agents can act not in the interests of principals, but in their own interests. Therefore, the agents' activity must be controlled. This requires additional cost - agency costs. All agency costs ultimately lay on the shoulders of the shareholders, thereby curbing the debt growth (Van Horne J. C., 2008).

The theory of asymmetric information was developed by the Nobel laureate Michael Spence. In the frameworks of this theory we are interested in Stefan Ross's scientific achievements (1977) about the research of the capital structure of the firm. The sense of this theory is that the managers having insider information give special signals to the market. That's why the theory is often called signaling theory. The important thesis of this theory is that in the capital structure must be more own resources then borrowed for the providing the reserve for the borrowed financing in the moment of appearance of new positive prospects of the firm development (Brigham E. F., 2008).

The theory of hierarchies associated with the names of Stewart Meyers and Nicholas Meylaff (1984). It explores three sources of financing for the corporation: firm's internal funds (reinvesting profits), borrowing capital, and issuing new shares. They should be used exclusively in that order. The theory of hierarchy confirms that the corporation can issue the shares only in case of their reevaluation. For this the managers of the firm must have more information than the market participants. In this, the theory of hierarchy has 
similarity with the signaling theory. In the context of capital structuring, this theory does not provide an optimal structure of capital and sources of its financing. That's why the debt level of the firm depends on its real needs.

These theories help to understand the nature of corporate capital structure and identify the potential internal and external factors. Many scientists tried to identify and research the relationship between the internal and external determinants and firm's capital structure. Based on their literature review we would like to notice some key internal factors, i.e. firm's characteristics which might have significant effect on the capital structure of the firm. For instance, the relationship between the profitability and capital structure was the subject of research of such scientists as: I. Friendand and L. Lang (1988), S. Barton and P. Gordon (1988), M. Harris and A. Raviv (1991), R. Rajan and L. Zingales (1995), L. Booth, V. Aivazian, A. Demirguc-kunt and V. Maksimovic (2001), P. Bauer (2004), D. Bastos, W. Nakamura and L. Basso (2009), G. Bokpin (2009); B. Dincergok and K. Yalciner (2011), W. Sbeti and I. Moosa (2012), R. Keshtkar, H. Valipour and A. Javanmard (2012), and etc.

The works of J. Warner (1977), J. Ang, J. Chua and J. McConnel (1982), R. Pettit and R. Singer (1985), S. Titman and R. Wessels (1988), D. Diamond (1989), M. Harris and A. Raviv (1991), R. Rajan and L. Zingales (1995), N. Michaelas, F. Chittenden and P. Poutzioris (1999), G. Hall, P. Hutchinson and N. Michaelas (2000), A. Bevan and J. Danbolt (2002), R. Korajczyk and A. Levy (2003), P. Bauer (2004), M. La Rocca, T. La Rocca, D. Gerace and C. Smark (2009), J. Hanousek and A. Shamshur (2011), T. Nguyen and J. Wu (2011), M. Lim (2012) and etc. considered the influence of the firm' size on the capital structure.

Moreover, we can learn about the impact of the liquidity on the capital structure decision from the works of A. Ozkan (2001), S. Myers and R. Rajan (1998), W. Sbeti and I. Moosa (2012). Or about the relationship between the asset tangibility and capital structure from the research of M. Jensen and V. Meckling (1976), S. Myers (1977), J. Scott (1977), L. Titman and R. Wessels (1988), R. La Porta, F. Lopez-de-Silanes, A. Shleifer, R. Vishny (1998), L. Booth, V. Aivazian, A. Demirguc-kunt and V. Maksimovic (2001), R. Korajczyk and A. Levy (2003), D. Bastos, W. Nakamura and L. Basso (2009), M. Frank and V. Goyal (2009), T. La Rocca, D. Gerace and C. Smark (2009), T. Nguyen and J. Wu (2011), W. Sbeti and I. Moosa (2012).

The connection between growth opportunity and capital structure was confirmed in the works of S. Myers (1977), S. Myers (1984), M. Jensen (1986), S. Titman and R. Wessels (1988), M. Harris and A. Raviv (1991), A. Ozkan (2001), P. Bauer (2004), N. Daskalakis and M. Psillaki (2008), T. La Rocca, D. Gerace and C. Smark (2009), M. Kouki and H. Said (2012).

The relations between all of these internal determinants and capital structure may be either positive or negative. It depends on the debt structure and the level of economic development in specific researched countries. Thus, a large part of researchers indicates that capital structure depends also on external factors due to firms are not operating in a "vacuum" environment. For example, Gross Domestic Product (GDP) is one of the most useful external financial determinants. Authors such as: Bastos, Nakamura \& Basso (2009), Bokpin (2009), Dincergok \& Yalciner (2011), Camara (2012) point out on the 
presence of a significant negative correlation between the corporate capital structure and the growth of GDP.

Furthermore, another not less popular financial determinant is the inflation level. The thoughts of scientist about the influence of this external factor are different. In particular, Bastos, Nakamura \& Basso (2009) refute the influence of inflation on the capital structure, while Sett \& Sarkhel (2010), Hanousek \& Shamshur (2011) point to a significant positive impact of macroeconomic conditions (including inflation rates) on capital structure. The connection between the leverage and benefits of the firm's shares is the subject of Masulis's study (1983). The scientist considers that the change of leverage is linked in proportion to the change in the yield of shares. But, Korteweg (2004), Dmitrov \& Jain (2008), Artikis \& Nifora (2011) concluded about the presence of negative connection between the leverage and share revenues.

Bokpin (2009) points on the significant positive effect of the interest rate on the capital structure of the corporation. Dincergok \& Yalciner (2011) refute this statement and prove the presence of the negative relationship between this factor and the capital structure.

The market capitalization (the determinant of the securities market development) has positive influence on the capital structure. This thesis is confirmed by the works of Dincergok \& Yalciner (2011) and Gajurel (2006). On the opposite side are conclusions of Bokpin (2009), Sett \& Sarkhel (2010). They point out a negative relationship between the capital structure and the development of the stock market.

The diversity of the conclusions of scientific works about the identification and the confirmation of the connection between the macroeconomic determinants and capital structure; its modeling according to the leverage and macroeconomic determinants requires own scientific research in this direction. Beside this, despite the presence of a number of studies dedicated to "capital structure process", there is still a gap for the Ukrainian financial market to be conducted.

\section{Methodology and empirical results}

\subsection{Description of data and variables}

In our research we use data of public firms, which are listed on the Ukrainian Stock Exchange (http://www.ux.ua/en/) for the period from 2012 to 2016. In our analysis we include only non-financial firms. Selected firms are belonging into several business sectors such as: metallurgical sector (KSTL, IGOK, PGZK, SGOK, CGOK, MGOK, DMKD, DMPZ, NITR, NVTR, SHCHZ, ZALK and MMKI); energy sector (TATM, PREN, KOEN, DNON, ZOEN, DNEN, KIEN, CEEN and ODEN); machine building sector (MSICH, SMACH, KRAZ, DMASCH, HMBZ, LUAZ, ZAZ and DVRB), food industry sector (MZKK, ROSHEN, MYRON, SUNI, UMHP); chemical industry sector (DNAZ, FARM, HEMO, KMED, YASK, BARVA, ZFER, AVDK); oil and gas sector (GLNG, UNAF); others (KORB, IFCEM, UTLM, ISKRA).

Firms data (property, plant and equipment; trade receivables; total current assets, total assets, trade liabilities; total current liabilities; short-term debt-loan; long-term debt- 
Ioan; total liabilities; total capital; sales revenues; EBIT; depreciation expenses and profit/loss) are taken from their official reporting: balance sheets and income statements (https://smida.gov.ua/). Data are organized in form of panel data and totally 49 firms are examined. On the other hand, market data (term spread, default spread, GDP growth rate and inflation) are taken from Official State Statistic of Ukraine (http://www.ukrstat.gov.ua/).

Table 1 presents definition of variables and abbreviations for both, firms' characteristics and macroeconomic factors.

Table 1: Definition of variables

\begin{tabular}{|c|c|c|}
\hline Variable & Abbreviation & Calculation \\
\hline \multicolumn{3}{|c|}{ Firm characteristics - Dependent variable } \\
\hline Leverage & LEV1 & Total liabilities / Total assets \\
\hline \multicolumn{3}{|c|}{ Firm characteristics - Independent variables } \\
\hline Tax shield & TaxS & Depreciation expenses / Total assets \\
\hline Tangibility & Tan & Property, plant and equipment/ Total assets \\
\hline Net trade credit & NTC & (Account receivables - account payables) / Sales \\
\hline Profitability & Prof3 & EBIT / Total assets \\
\hline Profitability & Prof2 & Profit (loss) / Total assets \\
\hline Firm's size & Size & Logarithm of sales \\
\hline \multicolumn{3}{|c|}{ Macroeconomic determinants } \\
\hline Economic growth & gdpgrowthrate & GDP current year $_{\text {/ GDP }}$ previous year ${ }^{*} 100 \%$ \\
\hline Default spread & defaultspread & $\begin{array}{l}\text { Yield of government bond Ukraine - } \\
\text { - Treasury bond yields uSA }\end{array}$ \\
\hline Inflation & inflation & $\begin{array}{c}\text { (Consumer Price Index current year } / \text { Consumer Price Index } \\
\text { previous year }-1 \text { ) } 100 \%\end{array}$ \\
\hline
\end{tabular}

From data distributions we can see that majority of observations come, first of all, from metallurgical sector ( 13 firms or $27 \%$ of overall number of firms), energy ( 9 firms or $18 \%$ ), chemical industry (8 firms or $16 \%$ ), machine building (8 firms or $16 \%$ ), food industry ( 5 firms or $10 \%$ ), others (4 firms or $8 \%$ ) and oil and gas sector ( 2 firms or $4 \%$ ). A common characteristic for selected firms can be that they have long-production cycle.

As Table 2 shows selected firms used on average high level of leverage. We chose to use this form of calculation for the leverage since it captured both, financial and non-financial liabilities (for example, creditors, i.e. accounts payables). On average, firms have financed assets $91 \%$ with liabilities, which in turns mean that rest $9 \%$ are financed with equity. Leverage has increased sharply during the examined period (see Fig. 2 and Fig. 3).

On average, firms have calculated and reported low level of depreciation expenses over total assets. It can be explained by several factors why this is so, but mainly probably from used depreciation methods. Since, selected firms have long production cycles that indicates using of heavy machineries (on average $41 \%$ ), property, equipment, technologies etc. and thus longer usage life, i.e. lower depreciation rates.

On average firms used more trade credit than provided and thus there is a negative net trade credit. From the time value of money perspective this is welcomed since have bought more than sold on credit and used account payables as an alternative financing fund.

Moreover, there is a positive EBIT over total assets as an alternative measure of profitability (see Prof3). 
On the other hand, on average there is a significant increased percentage of the country GDP, but in same time of inflation too.

Table 2: Summary statistics

\begin{tabular}{|c|c|c|c|c|c|c|c|c|c|}
\hline & Min. & 1stQ. & Mean & Median & 3rdQ. & Max. & St.dev. & Skewn. & Kurt. \\
\hline LEV1 & 0.04 & 0.34 & 0.91 & 0.53 & 0.79 & 27.06 & 2.57 & 8.91 & 83.28 \\
\hline TaxS & 0 & 0.02 & 0.05 & 0.04 & 0.07 & 0.7 & 0.06 & 6.07 & 55.59 \\
\hline Tan & 0 & 0.19 & 0.41 & 0.41 & 0.62 & 0.94 & 0.25 & 0.16 & -1.08 \\
\hline NTC & -290109 & 0.02 & -1181.89 & 0.16 & 0.61 & 1652.04 & 18573.08 & -15.43 & 237.01 \\
\hline Prof3 & -0.21 & 0.04 & 0.14 & 0.1 & 0.21 & 0.62 & 0.14 & 1.04 & 1.28 \\
\hline Prof2 & -9.42 & -0.05 & -0.1 & 0 & 0.06 & 0.7 & 0.82 & -9.41 & 95.31 \\
\hline Size & 0.69 & 13.36 & 14.49 & 14.99 & 16.02 & 17.79 & 2.09 & -1.78 & 7.19 \\
\hline defaultspread & 5 & 6 & 7.55 & 7.5 & 9.23 & 10 & 1.89 & -0.02 & -1.55 \\
\hline gdpgrowthrate & 104.3 & 107.7 & 113.3 & 107.8 & 120.4 & 126.3 & 8.53 & 0.48 & -1.5 \\
\hline inflation & 99.8 & 100.5 & 116.18 & 112.4 & 124.9 & 143.3 & 16.4 & 0.56 & -1.12 \\
\hline
\end{tabular}

Most of the variables have non-standard asymmetric distributions with high positive or negative kurtosis. $60 \%$ of variables are skewed positively, revealing longer right tail. The distributions of some variables have outliers, for example, NTC, LEV1 and Prof2. The outliers are clearly observed on histograms, presented on Fig. 1.
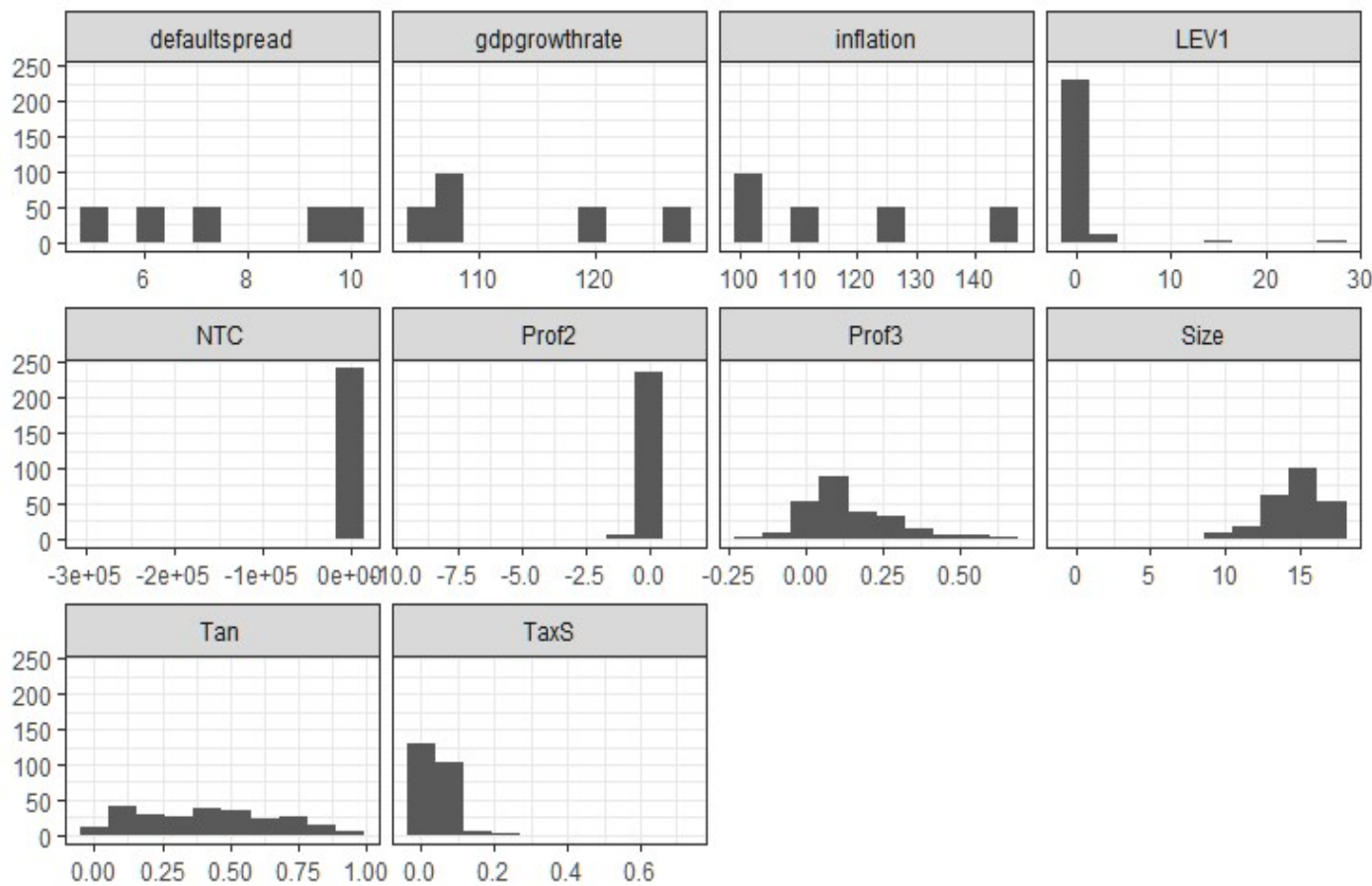

Fig. 1. Histograms for the variables under consideration. 
The dependent variable $L E V 1$, averaged by firms, is plotted on Fig. 2, which also contains the estimated linear trend with confidence region. Fig. 2 gives strong evidence of the existence of the uptrend in the leverage dynamics among analyzed firms during the sample period.

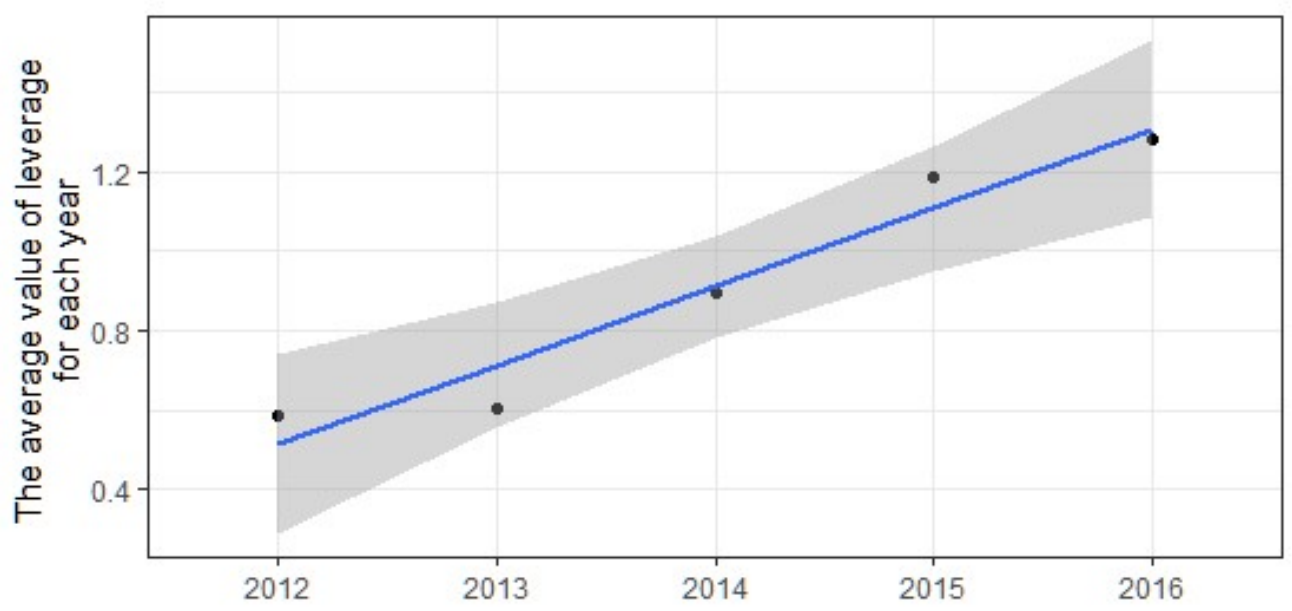

Fig. 2. The average value of leverage for each year with a trend line and confidence region.

The same trend is demonstrated by economic growth, evaluated gdpgrowthrate variable (see Table 1 for details). This relation is depicted on Fig. 3.
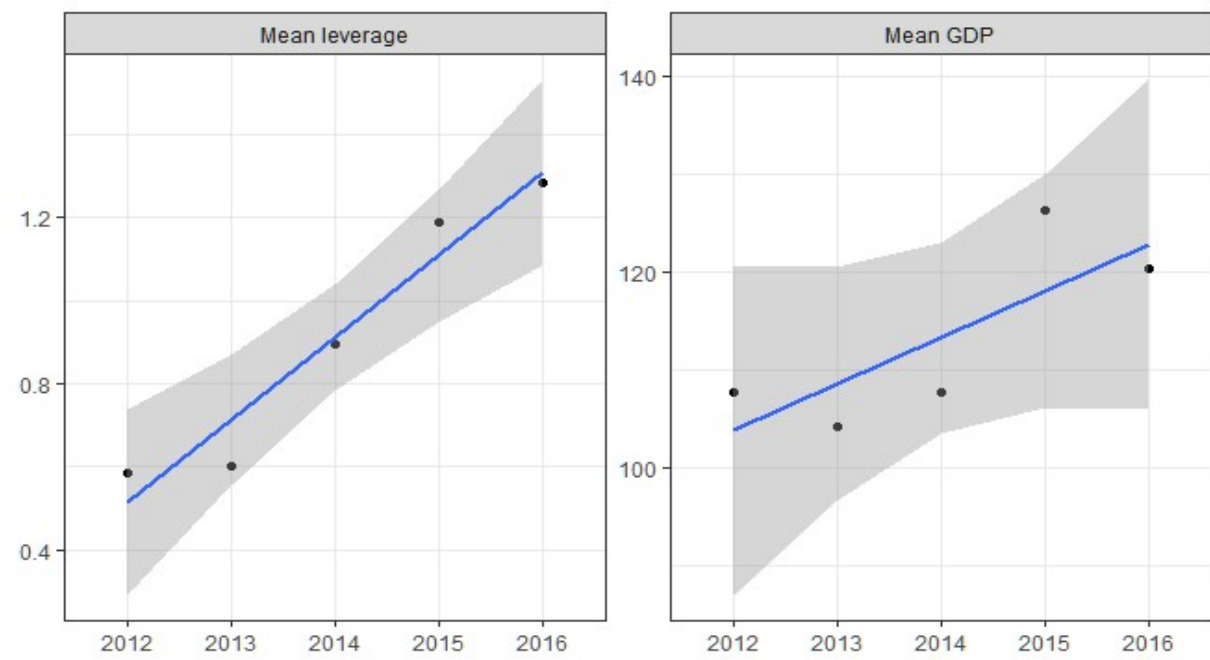

Fig. 3. The average values of leverage and GDP with trend and confidence regions.

The correlation between variables under consideration, calculated in Table 3, confirms the positive relation between gdpgrowthrate and LEV1. 
From correlation results there are some preliminary findings such as: (1) firms with higher tax shield, lower tangibility, lower net trade credit and profitability used more leverage than counterparties; (2) larger firms used less leverage than counterparties; and (3) as the macroeconomic factors are increased, leverage increased too.

Table 3: Correlation between variables

\begin{tabular}{|c|c|c|c|c|c|c|c|c|c|c|}
\hline & $\begin{array}{c}\text { default } \\
\text { spread }\end{array}$ & $\begin{array}{c}\text { gdpgro } \\
\text { wthrate }\end{array}$ & $\begin{array}{c}\text { inflat } \\
\text { ion }\end{array}$ & $\begin{array}{c}\text { LEV } \\
1\end{array}$ & TaxS & Tan & NTC & Prof2 & Prof3 & Size \\
\hline defaultspread & 1 & 0.9 & 0.82 & 0.11 & -0.08 & -0.08 & -0.08 & -0.11 & -0.01 & -0.02 \\
\hline $\begin{array}{c}\text { gdpgrowthrat } \\
\text { e }\end{array}$ & 0.9 & 1 & 0.73 & 0.1 & -0.06 & -0.08 & -0.1 & -0.08 & 0.01 & -0.02 \\
\hline inflation & 0.82 & 0.73 & 1 & 0.08 & -0.04 & -0.06 & -0.11 & -0.13 & 0 & -0.04 \\
\hline LEV1 & 0.11 & 0.1 & 0.08 & 1 & 0.11 & -0.02 & -0.63 & -0.87 & -0.09 & -0.41 \\
\hline TaxS & -0.08 & -0.06 & -0.04 & 0.11 & 1 & 0.32 & -0.06 & -0.13 & 0.05 & 0.04 \\
\hline Tan & -0.08 & -0.08 & -0.06 & -0.02 & 0.32 & 1 & -0.02 & -0.04 & -0.09 & 0.07 \\
\hline NTC & -0.08 & -0.1 & -0.11 & -0.63 & -0.06 & -0.02 & 1 & 0.73 & 0.06 & 0.42 \\
\hline Prof2 & -0.11 & -0.08 & -0.13 & -0.87 & -0.13 & -0.04 & 0.73 & 1 & 0.11 & 0.4 \\
\hline Prof3 & -0.01 & 0.01 & 0 & -0.09 & 0.05 & -0.09 & 0.06 & 0.11 & 1 & 0.13 \\
\hline Size & -0.02 & -0.02 & -0.04 & -0.41 & 0.04 & 0.07 & 0.42 & 0.4 & 0.13 & 1 \\
\hline
\end{tabular}

\subsection{Estimation methodology}

In the section below are presented and discussed determinants which are used in regression analysis (Table 4).

The paper is aimed at studying the process of leverage adjusting. To take into account the heterogeneity of firms we use dynamic panel regression with individual effects. In line with (Drobetz, Wanzenried, 2006) we apply equation (1) below for the equity adjustment process.

$$
L E V_{i t}-L E V_{i, t-1}=\delta\left(L E V_{i t}^{*}-L E V_{i_{1} t-1}\right)
$$

where $L E V_{t}$ is ith firm leverage a time $t, \delta$ characterized the speed of adjustment and $0 \leq \delta \leq 1, \mathrm{LEV}_{\mathrm{t}}^{*}$ is target leverage, which is modeled as in equation (2).

$$
L E V_{t}^{*}=\beta^{v} x_{i t}+u_{i t}
$$

where $\mathrm{x}_{\mathrm{it}}$ are explanatory variables, $\beta$ is a vector of coefficients, $\mathbf{u}_{\mathrm{it}}$ is error term. The equations above yield equation (3).

$$
L E V_{i t}=(1-\delta) L E V_{i_{i} t-1}+\delta \beta^{\prime} x_{i t}+u_{i t}
$$


The error term $u_{i t}$ can be represented as the sum of individual effects $\lambda_{i}$ and white noise $v_{i t}$. We estimate the last equation by GMM as proposed in Arellano and Bond (1991).

Going back to equation (1) typically can be three cases regarding adjustment speed value. Firstly, if $\delta=0$ then $L E V_{i t}=L E V_{i, t-1}$. This is the case where actual year leverage financing is similar as previous one.

Secondly, if $\delta=1$ then $L E V_{i t}=L E V_{i, t}^{*}$. This is the case where firms adjust full leverage financing toward the aimed ratio.

Thirdly, if $0<\delta<1$ then there is a deviation between actual and aimed leverage ratio. This is our examined case and the speed of adjustment is $21 \%$. In turns, it means that firms need around 5 years to achieve the aimed full leverage level.

\subsection{Empirical results}

The estimates of equation (3), obtained by (Arellano, Bond 1991) method, are in Table 2. We use the second and the third lags of the dependent variable as instruments. We also add Prof2 to the instrument variable set.

Table 4: Estimation results

\begin{tabular}{|l|l|l|l|l|l|}
\hline & Estimate & Std.Error & z-value & $\operatorname{Pr}(>|\mathbf{z}|)$ & \\
\hline$L E V_{i, t-1}$ & 0.7884 & 0.0096 & 82.2401 & 0.0000 & *** \\
\hline TaxS & 3.9621 & 1.9863 & 1.9947 & 0.0461 & $* *$ \\
\hline Tan & 1.7435 & 0.4705 & 3.7058 & 0.0002 & *** \\
\hline NTC & 0.0000 & 0.0000 & -15.6860 & 0.0000 & *** \\
\hline Prof3 & 1.2497 & 0.4873 & 2.5644 & 0.0103 & ** \\
\hline Size & -0.0734 & 0.0460 & -1.5959 & 0.1105 & \\
\hline gdpgrowthrate & -0.0522 & 0.0106 & -4.9454 & 0.0000 & $* *$ \\
\hline defaultspread & 0.3764 & 0.0738 & 5.0985 & 0.0000 & $* *$ \\
\hline inflation & -0.0018 & 0.0015 & -1.1718 & 0.2413 & \\
\hline & & & & & \\
\hline Wald test & & & 95905.9100 & 0.0000 & $*$ \\
\hline Sargan-Hansen test & & & 30.4039 & 0.0160 & $*$ \\
\hline AR(1) in residuals test & & & -1.1745 & 0.2402 & \\
\hline AR(2) in residuals test & & & -0.6676 & 0.5044 & \\
\hline
\end{tabular}

Significance level: ${ }^{* *}-1 \%,{ }^{* *}-5 \%,{ }^{*}-10 \%$.

The regression is significant on any reasonable level according to Wald test. The null hypothesis of Sargan-Hansen test is not rejected on $5 \%$ level, indicating the validity of instruments. The estimated adjustment speed is about 0.21 and significant on any reasonable level. As for macroeconomic factors, inflation is insignificant. In contrast 
gdpgrowthrate and defaultspread do influence the level of leverage. The first impacts negatively and the second increases the leverage.

It's worth mentioning that the hypotheses of the first and the second order autocorrelation absence in the regression residuals are not rejected according to the test proposed in (Arellano, Bond 1991), Table 4.

\section{Conclusion}

In this paper we aimed to examine the relationship between leverage and some selected firms' characteristics, and macroeconomic determinants for a sample of 49 Ukrainian firms from 2012 to 2016. Among other results we found that on average terms, firms used high level of leverage. This is less or more an ambitious finding which requires further tests why firms decided to use such high level of leverage financing.

From correlation analysis we found that firms with higher tax shield, lower tangibility, lower net trade credit and profitability used more leverage than counterparties; as the macroeconomic factors are increased, leverage is increased too; and larger firms used less leverage than counterparties. Moreover, actual leverage was significantly affected by previous ones and by firms' characteristics such as: tax shield, tangibility, net trade credit and profitability. Firm's size from regression results was confirmed not to play a role in the leverage decision making process. Also, GDP growth rates and default spread were confirmed as significant determinants on financing policies.

\section{References}

Ang, J.S., Chua, J.H., McConnell, J.J., (1982), The administrative costs of corporate bankruptcy: a note. The Journal of Finance, Vol. 37, no. 1, pp. 219-226.

Arellano, M., and Bond, S., (1991), Some tests of specification for panel data: Monte Carlo evidence and an application to employment equations. Review of Economic Studies, Vol. 58, no. 2, pp. 277-297.

Artikis, P. G. \& Nifora, G., (2012), Capital structure, macroeconomic variables \& stock returns. Evidence from Greece, International Advances in Economic Research, Vol. 12, pp. 87-101. http://dx.doi.org/10.1007/s11294-011-9334-z

Barton, S. L., \& Gordon, P. J., (1988), Corporate strategy and capital structure, Strategic Management Journal, Vol. 9, no. 6, pp. 623-632. http://dx.doi.org/10.1002/smj.4250090608

Bastos, D. D., Nakamura, W. T., \& Basso, L. F. C., (2009), Determinants of capital structure of publicly-traded companies in Latin America: the role of institutional and macroeconomic factors, Journal of International Finance and Economics, Vol. 9, no. 3, pp. 24-39.

Bauer, P., (2004), Determinants of capital structure: Empirical evidence from Czech Republic. Czech Journal of Economics and Finance, Vol. 54, no. 1-2, pp. 2-21.

Bevan, A.A., Danbolt, J., (2002), Capital structure and its determinants in the uk - a decompositional analysis. Applied Financial Economic, Vol. 12, no. 3, pp. 159-170.

Bokpin, G. A., (2009), Macroeconomic development and capital structure decisions of firms: evidence from emerging market economies, Studies in Economics and Finance, Vol. 26, no. 2, pp. 129-142. http://dx.doi.org/10.1108/10867370910963055 
Booth, L., Aivazian, V., Demirguc-kunt, A., Maksimovic, V., (2001), Capital structures in developing countries, The Journal of Finance, Vol. 56, no. 1, pp. 78-130. https://doi.org/10.1111/00221082.00320

Brigham E. F. and Ehrhardt M.C., (2008): Financial Management: Theory and Practice. [12th Edition]. Mason, OH, USA: Thomson South-Western, $1074 \mathrm{p}$.

Camara, O., (2012), Capital structure adjustment speed and macroeconomic conditions: U.S. MNCs and DCs, International Research Journal of Finance and Economics, Vol. 84, pp. 106-120.

Daskalakis, N. \& Psillaki, M., (2008), Do country or firm factors explain capital structure? Evidence from SMEs in France and Greece, Applied Financial Economics, Vol. 18, no. 1, pp. 87-97. http://dx.doi.org/10.1080/09603100601018864

Diamond, D.W., (1989), Reputation acquisition in debt markets. Journal of Political Economy, Vol. 97, no. 4, pp. 828-862.

Dincergok, B., \& Yalciner, K., (2011), Capital structure decisions of manufacturing firms' in developing countries, Middle Eastern Finance and Economics, Vol. 12, pp. 86-100.

Drobetz, W., \& Wanzenried, G., (2006), What determines the speed of adjustment to the target capital structure?. Applied Financial Economics, Vol. 16, no. 13, pp. 941-958.

Durand D. (1952): Costs of Debt and Equity Funds for Business: Trends and Problems of Measurement. Conference on Research in Business Finance, 1952, National Bureau of Economic Research. NBER, pp, 215-262.

Frank, M. Z., \& Goyal, V. K., (2009), Capital structure decisions: which factors are reliably important? Financial management, Vol. 38, no. 1, pp. 1-37. http://dx.doi.org/10.1111/j.1755053X.2009.01026.X

Friend, I., Lang, L.H.P., (1988), An empirical test of the impact of managerial self-interest on corporate capital structure. The Journal of Finance, Vol. 43, no. 2, pp. 271-281.

Gajurel, D. P. (2006). Macroeconomic influences on corporate capital structure, available online at http://ssrn.com/abstract=899049 or http://dx.doi.org/10.2139/ssrn.899049

Hall, G., Hutchinson, P. \& Michaelas, N., (2000), Industry effects on the determinants of unquoted SMEs' capital structure, International Journal of the Economics of Business, Vol. 7, no. 3, pp. 297-312. http://dx.doi.org/10.1080/13571510050197203

Hanousek, J. \& Shamshur, A., (2011), A stubborn persistence: Is the stability of leverage ratios determined by the stability of the economy? Journal of Corporate Finance, Vol. 17, pp. 13601376. http://dx.doi.org/10.1016/j.jcorpfin.2011.07.004

Harris, M., Raviv, A., (1991), The theory of capital structure. The Journal of Finance, Vol. 46, no. 1, pp. 297-355.

Jensen M. C., Meckling W.H., (1976), Theory of the Firm: Managerial Behavior, Agency Costs and Ownership Structure. Journal of Financial Economics. Vol. 3, no. 4. pp. 305-360.

Keshtkar, R., Valipour, H. \& Javanmard, A., (2012), Determinants of corporate capital structure under different debt maturities: empirical evidence from Iran, International Research Journal of Finance and Economics, Vol. 90, pp. 46-53.

Korajczyk, R. A., \& Levy, A., (2003), Capital structure choice: macroeconomic conditions and financial constrains, Journal of Financial Economics, Vol. 68, no. 1, pp. 75-109. http://dx.doi.org/10.1016/S0304-405X(02)00249-0

Kouki, M. \& Said, H. B., (2012), Capital structure determinants: new evidence from French panel data, International Journal of Business and Management, Vol. 7, no. 1, pp. 214-229.

Kraus A. A., Litzenberger R.H., (1973), State-Preference Model of Optimal Financial Leverage, The Journal of Finance, Vol. 28, no. 4, pp. 911-922.

La Porta, R., Lopez-de-Silanes, F., Shleifer, A., Vishny, R., (1998), Law and finance. Journal of Political Economy, Vol. 106, no. 6, pp. 1113-1150. 
La Rocca, M., La Rocca, T., Gerace, D., Smark, C., (2009), Effect of diversification on capital structure. Accounting Finance, Vol. 49, no. 4, pp. 799-826.

Lim M, T. C. (2012). Determinants of capital structure: empirical evidence from financial services listed firms in China, International Journal of Economics and Finance, Vol. 4, no. 3, pp. 191203.

Michaelas, N, Chittenden, F. \& Poutzioris, P., (1999), Financial policy and capital structure choice in U.K. SMEs: empirical evidence from company panel data, Small Business Economics, Vol. 12, no. 2, pp. 113-130. http://dx.doi.org/10.1023/A:1008010724051

Miller M., (1977), Debt and Taxes. The Journal of Finance, Vol. 32, no. 2, pp. 261-275.

Modigliani F., Miller M., (1963), Corporate Income Taxes and the Cost of Capital: A Correction, American Economic Review, Vol. 53, no. 3, pp. 433-443.

Modigliani, F. and Miller, M.H., (1958), The Cost of Capital, Corporation Finance and the Theory of Investment. American Economic Review, Vol. 48, no. 3, pp. 261-297.

Myers S.C., Majluf N.S., (1984), Corporate Financing and Investment Decisions when Firms Have Information that Investors Do Not Have. Journal of Financial Economics, Vol. 13, no. 3, pp. 187-221. https://doi.org/10.1016/0304-405X(84)90023-0

Myers, S., (1977), Determinants of corporate borrowing. Journal of Financial Economics, Vol. 5, no. 2, pp. 147-175.

Myers, S.C., (1984), The capital structure puzzle. The Journal of Finance, Vol. 39, no. 3, pp. 575592.

Myers, S.C., Rajan, R.G., (1998), The paradox of liquidity. The Quarterly Journal of Economics, Vol. 113 , no. 3, pp. 733-771.

Nguyen, Tho and Wu, Jian, (2011), Capital Structure Determinants and Convergence (January 6, 2011). Bankers, Markets and Investors, forthcoming, available online at SSRN: https://ssrn.com/abstract=1735804

Ozkan, A., (2001), Determinants of capital structure and adjustment to long run target: evidence from UK company panel data. Journal of Business Finance and Accounting. Vol. 28, no. 1-2, pp. 175-198.

Pettit, R., Singer, R., (1985), Small business finance: a research agenda. Financial Management, Vol. 14, no. 3, pp. 47-60.

Rajan, R.G., Zingales, L., (1995), What do we know about capital structure? Some evidence from international data. The Journal of Finance, Vol. 50, no. 5, pp. 1421-1460.

Ross S. A., (1977), The Determination of Financial Structure: The Incentive-Signalling Approach. The Bell Journal of Economics, Vol. 8, no. 1, pp. 23-40.

Sbeti, W.M., Moosa, I., (2012), Firm-specific factors as determinants of capital structure in the absence of taxes. Applied Financial Economics, Vol. 22, no. 3, pp. 209-213.

Scott, J., (1977), Bankruptcy, secured debt, and optimal capital structure. The Journal of Finance, Vol. 32, no. 1, pp. 1-19.

Sett, K. \& Sarkhel, J., (2010), Macroeconomic variables, financial sector development and capital structure of Indian private corporate sector during the period 1981-2007. The IUP Journal of Applied Finance, Vol. 16, no. 1, pp. 40-56.

Solomon E., (1955), Economic Growth and Common Stock Values. Journal of Business, Vol. 28, no. 2, pp. 213-221.

Titman, S., Wessels, R., (1988), The determinants of capital structure choice. The Journal of Finance, Vol. 43, no. 1, pp. 1-19.

Van Horne J. C., Wachowicz J.M.Jr. (2008): Fundamentals of Financial Management [13th Edition]. Harlow (England), London, New York: Prentice Hall Inc., Financial Times, 719 p.

Warner, J.B., (1977), Bankruptcy costs: some evidence. The Journal of Finance, Vol. 32, no. 2, pp. 337-347. 
Weston J. F., (1963), A Test of Cost of Capital Propositions. Southern Economic Journal, Vol. 30, no. 1 , pp. 105-112.

\section{Links (firms web pages):}

http://www.arcelormittal.com.ua/

http://ingok.metinvestholding.com/ua

http://www.ugok.info/

http://sevgok.metinvestholding.com/ua

http://cgok.metinvestholding.com/ua

http://mgok.dp.ua/

http://www.dmkd.dp.ua/

http://www.dmpz.dn.ua/

http://www.ntz.dp.ua/

http://www.nmpp.interpipe.biz/

http://www.kz1.donetsk.ua/

http://www.zalk.com.ua/

http://ilyichsteel.metinvestholding.com/

http://www.turboatom.com.ua/

http://www.ol.if.ua/

http://www.aes-ukraine.com/kyiv

http://www.doe.com.ua/

http://www.energo.uz.ua/

http://www.dniproenergo.ua/

http://www.kievenergo.com.ua/

http://www.centrenergo.com/

https://oblenergo.odessa.ua/

http://www.motorsich.com/

http://snpo.ua/

http://www.autokraz.com.ua/

http://dvmash.biz/

http://www.shaht.kharkov.ua/

http://www.bogdan.ua/

http://www.avtozaz.com/ua/

http://dvrb.dp.ua/

https://www.mhp.com.ua/

https://roshen.com/

https://graintrade.com.ua/elevator/mironivske-hpp-pat-id1121

http://www.suninterbrew.ua/

http://www.mhp.com.ua/

http://www.azot.com.ua/

http://www.farmak.ua/

http://www.hemoplast.ua/ua/main/

http://www.arterium.ua/about/history/kmp.php

http://yakhz.donetsksteel.com/

http://www.barva.com.ua/ru/

http://www.zfz.com.ua/

http://www.akhz.com.ua/

http://www.galnaftogas.com/

http://www.ukrnafta.com/ 
https://korchuvatskiy-kombinat-budivelnih-materialiv.business-guide.com.ua/ http://www.ifcem.if.ua/

http://www.ukrtelecom.ua/

http://www.iskra.com.ua/ 